\title{
Zastosowanie radioterapii sterowanej obrazem (IGRT) za pomocą kilowoltowej stożkowej tomografii komputerowej (kV CBCT) w codziennej praktyce klinicznej
}

\author{
Joanna Topczewska-Bruns ${ }^{1}$, Tomasz Filipowski ${ }^{1}$, \\ Robert Chrenowicz ${ }^{2}$, Barbara Pancewicz-Janczuk ${ }^{2}$, Ewa Rożkowska ${ }^{1}$
}

\begin{abstract}
Nowoczesne techniki radioterapii, takie jak IMRT czy stereotaktyczna radiochirurgia, wymagają precyzyjnej lokalizacji obszaru napromienianego. Jedną z form radioterapii sterowanej obrazem (IGRT) jest weryfikacja położenia obszarów tarczowych przed seansem radioterapii za pomocą kilowoltowej, stożkowej tomografii komputerowej (kV CBCT). Dokładne poznanie sposobu pozyskiwania obrazu i jego rekonstrukcji za pomocą kV CBCT oraz metod jego porównania z obrazem wykorzystanym do planowania leczenia są niezbędne do właściwej interpretacji informacji o położeniu obszaru do napromieniania. Niniejsza praca przedstawia zasadę działania i implikacje kliniczne zastosowania kV CBCT we współczesnej radioterapii.
\end{abstract}

\section{Use of kilovoltage cone beam computer tomography (kV CBCT) in image-guided radiotherapy (IGRT) in daily clinical practice}

Precise target localization is necessary for modern radiotherapy techniques such as intensive modulated radiotherapy (IMRT). One example of image-guided radiotherapy (IGRT) is the use of kilovoltage cone beam computer tomography (kV CBCT) performed before the therapeutic irradiation. In-depth knowledge of image acquisition and image reconstruction methods used in $\mathrm{kV} \mathrm{CBCT}$ as well as image comparison methods used to compare those images and images used for treatment planning, is required for proper interpretation of the results of target localization. This paper describes the fundamental principles of kV CBCT and their clinical implications in contemporary radiotherapy.

NOWOTWORY Journal of Oncology 2013; 63, 4: 305-310

Słowa kluczowe: IGRT, radioterapia, kilowoltowa stożkowa tomografia komputerowa, rekonstrukcja obrazu Key words: IGRT, radiotherapy, kilovoltage cone beam computer tomography, imaging reconstruction

\section{Znaczenie IGRT we współczesnej radioterapii}

Onkologia XXI wieku to doskonały przykład wielodyscyplinarnego leczenia pacjenta. Zastosowanie leczenia systemowego opartego o klasyczne cytostatyki, leki celowane molekularnie czy też hormonoterapię często łączone jest z miejscowym leczeniem w postaci chirurgii bądź radioterapii. Dynamiczny rozwój przemysłu komputerowego szybko znalazł praktyczne zastosowanie w leczeniu energią jonizującą. Nie sposób wyobrazić sobie dzisiejszej radioterapii bez użycia tomografii komputerowej, systemów planowania leczenia czy też w pełni zintegrowanych sposobów dostarczania dawki promieniowania, gdzie dzięki kolimatorom wielolistkowym, dynamicznym klinom etc. możliwe jest bardzo precyzyjne napromienienie obszaru guza nowotworowego z jednoczesnym zaoszczędzeniem zdrowych tkanek i narządów. Aby jednak realizacja radioterapii przebiegała zgodnie z przyjętym planem, niezmiernie istotna we współczesnej radioterapii jest precyzyjna lokalizacja obszaru leczenia [1].

${ }^{1}$ Zakład Radioterapii

${ }^{2}$ Zakład Fizyki Medycznej

Białostockie Centrum Onkologii 


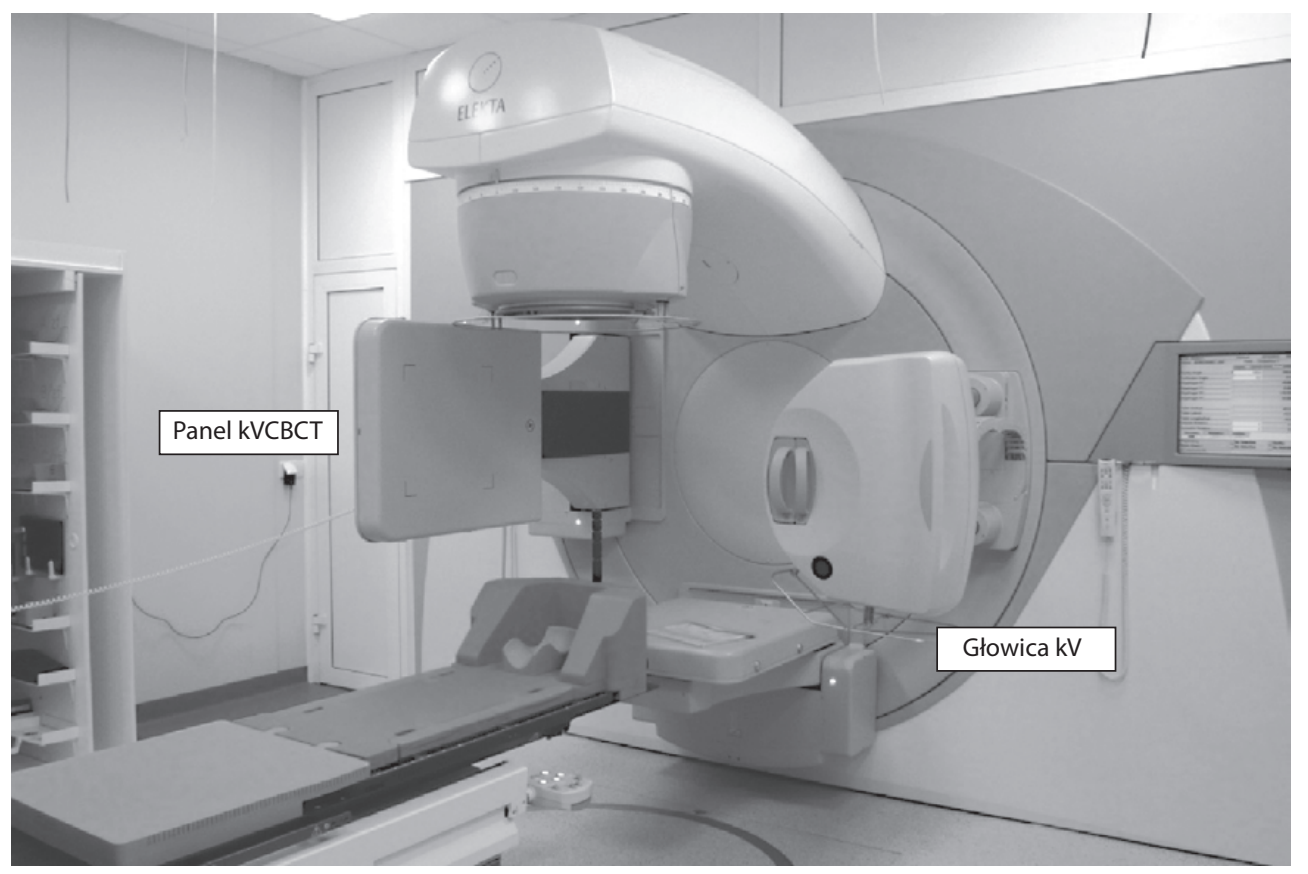

Rycina 1. Akcelerator zintegrowany z kV CBCT (Synergy, Elekta)

Od ponad dwóch dekad możliwa jest weryfikacja ułożenia pacjenta na aparacie terapeutycznym tuż przed ekspozycją na promieniowanie jonizujące. Istnieje szereg metod wspólnie określanych jako IGRT (Image Guided Radiation Therapy — radioterapia sterowana obrazem), które umożliwiają sprawdzenie i ewentualną korektę ułożenia pacjenta przed zabiegiem lub w trakcie realizacji radioterapii. Jedną z najstarszych opcji jest wykonanie zdjęć portalowych za pomocą wiązki megawoltowej przyśpieszacza liniowego i porównanie struktur kostnych do referencyjnych obrazów z systemu planowania (DRR) [2-7]. Technika ta umożliwia jednak wyłącznie dwuwymiarową analizę położenia pacjenta na stole terapeutycznym. Podobne dane uzyskuje się po wykonaniu zdjęć rentgenowskich w płaszczyznach prostopadłych (2D-2DkV) [8, 9].

Największym przełomem w ostatnich latach jest wprowadzenie do praktyki klinicznej zintegrowanych z akceleratorami narzędzi do trójwymiarowej rekonstrukcji obrazów, czy to w postaci CT-on rails - (komputerowy tomograf wielorzędowy poruszający się na szynach w pomieszczeniu z akceleratorem), czy też tomografii komputerowej realizowanej za pomocą wiązki megawoltowej przyśpieszacza (MV CBCT), bądź też za pomocą kilowoltowej wiązki stożkowej lampy rentgenowskiej dołączonej do ramienia przyśpieszacza (kV CBCT) [10-13]. Nałożenie przestrzenne obrazów $z$ tomografii referencyjnej do planowania leczenia z obrazem lokalizacyjnym uzyskanym przed napromienianiem w bunkrze akceleratora wnosi szereg informacji o różnicach w położeniu obszarów tarczowych i tkanek zdrowych [14]. Ponad roczne doświadczenia własne z zastosowaniem sy-

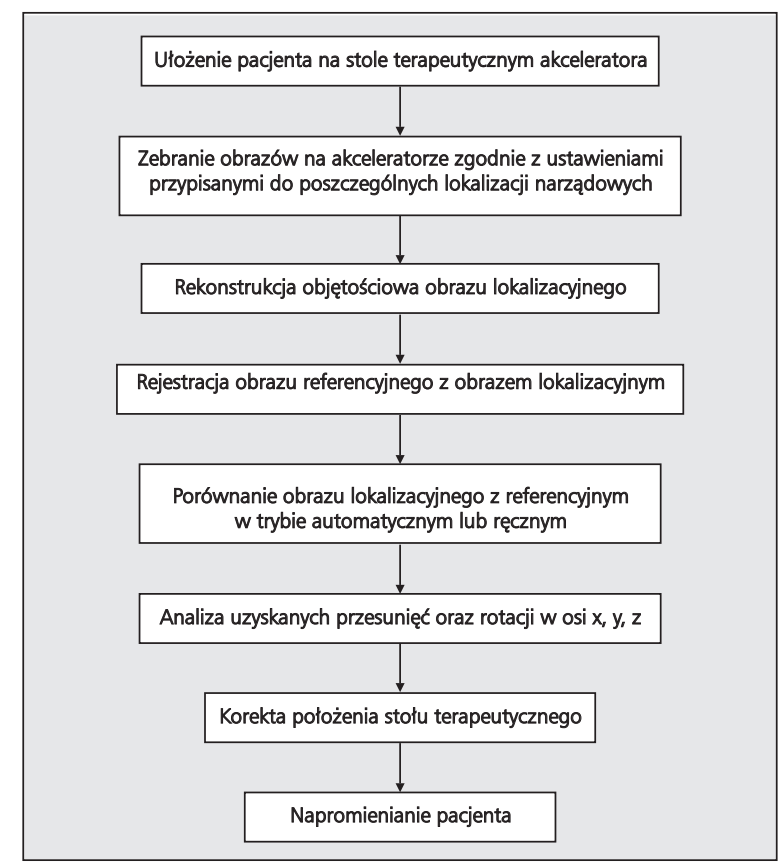

Rycina 2. Schemat weryfikacji ułożenia pacjenta na akceleratorze za pomocą kV CBCT (XVI, Elekta)

temu kV CBCT (XVI v. 4.2, Elekta - ryc. 1) zrodziły szereg refleksji nad czynnikami wpływającymi na ostateczny wynik niezgodności pozycjonowania pacjenta, prezentowanymi jako składowe wektora przesunięcia. Sposób detekcji, rekonstrukcji i fuzji obrazu wykonanego przy pomocy kV CBCT może wprowadzić klinicystów w niemałe zakłopotanie prawie na każdym etapie jego użytkowania (ryc. 2). 
Wydaje się, iż poznanie i zrozumienie zasad działania kV CBCT jest niezbędne do właściwego i świadomego zastosowania trójwymiarowej weryfikacji ułożenia pacjenta na stole terapeutycznym.

\section{Budowa oraz zasada działania kV CBCT (XVI, Elekta)}

System XVI (X-ray Volume Imaging) jest przykładem tomografii komputerowej, gdzie obraz zbierany jest za pomocą kilowoltowej (kV) wiązki stożkowej (CB). Urządzenie kV CBCT składa się z lampy rentgenowskiej i cyfrowego panelu, ustawionych względem siebie pod kątem 180 stopni. Oba elementy umocowane są bezpośrednio do ramienia akceleratora. Przed wykonaniem akwizycji należy wybrać odpowiednie parametry detekcji obrazu (tzw. presety), tj. szerokość pola widzenia (FOV) lampy rentgenowskiej, obecność filtra łukowego (bowtie), a także zakres i prędkość ruchu ramienia. Poza presetami dostarczonymi bezpośrednio przez producenta użytkownik ma możliwość tworzenia własnych konfiguracji zbierania obrazów w zależności od potrzeb klinicznych, co ma szczególne znacznie m.in. przy realizacji radioterapii u dzieci [15]. Należy mieć na uwadze, że wykonanie kV CBCT powoduje ekspozycję na promieniowanie jonizujące [16]. Dawka, jaka dostarczana jest w trakcie przeprowadzania kV CBCT, zależy m.in. od typu użytego presetu, tj. napięcia lampy rentgenowskiej, czasu detekcji obrazu, zastosowania filtra łukowego, jak też od lokalizacji anatomicznej, w zakresie której ma miejsce akwizycja danych, oraz od masy ciała pacjenta [17-20]. Ważnym jest również podjęcie decyzji przed wykonaniem kV CBCT, jakie struktury anatomiczne będą brane pod uwagę przy dopasowywaniu obrazów referencyjnych z lokalizacyjnymi, gdyż uzyskanie obrazu o lepszej rozdzielczości dla tkanek miękkich wymaga zastosowania innych parametrów niż dla obrazu o dobrej jakości dla struktur kostnych. W zależności od konstelacji FOV, filtra i zakresu obrotu ramienia dawki deponowane w czasie jednej akwizycji wahają się od 0,9 mGy w przypadku zbierania obrazów w obrębie głowy i szyi do 25 mGy w miednicy [21].

Oprogramowanie komputerowe wykorzystujące algorytm Feldkampa-Davisa-Kressa umożliwia rekonstruowanie obrazu w czasie akwizycji, dzięki czemu obraz lokalizacyjny można poddawać analizie tuż po zakończeniu zbierania obrazów przez detektor sytemu XVI [22]. Trójwymiarowa rekonstrukcja obrazu na stacjach tego systemu możliwa jest na trzech poziomach jakości: niskim, średnim i wysokim. Wysoka jakość rekonstrukcji umożliwia uzyskanie obrazu o wysokiej rozdzielczości (1024 pikseli), ale kosztem wydłużenia czasu do jego powstania (około 3,5 min). Natomiast rekonstrukcja średniej lub niskiej jakości daje niższą rozdzielczość obrazu (odpowiednio 512 i 250 pikseli), lecz w czasie znacznie krótszym (około 1,5 min). Zastosowanie rekonstrukcji obrazu w średniej rozdzielczości może powodować różnicę w wektorze przesunięcia poniżej $1 \mathrm{~mm}$ w stosunku do obrazu rekonstruowanego w wysokiej rozdzielczości.
Biorąc pod uwagę znacznie krótszy czas potrzebny do uzyskania obrazu, wydaje się, iż rekonstrukcja średniej jakości jest wystarczająca w codziennej praktyce klinicznej [23].

Należy podkreślić, że jakość obrazu uzyskanego za pomocą kV CBCT istotnie różni się od uzyskanego za pomocą wielorzędowej CT [24] (ryc. 3). Ma to szczególne znaczenie, gdy analiza przesunięć pacjenta na aparacie terapeutycznym odbywa się w oparciu o obraz tkanek miękkich, a nie struktur kostnych. Szczególnie niekorzystny wpływ na jakość obrazu ma promieniowanie rozproszone powstające $w$ ciele pacjenta w czasie zbierania obrazów przy użyciu XVI [25, 26]. Może być ono zmniejszone m.in. za pomocą redukcji objętości obszaru poddawanego skanowaniu (zmniejszenie FOV) oraz przez zastosowanie filtra łukowego $[27,28]$. Poprawa jakości obrazów lokalizacyjnych jest przedmiotem intensywnych prac badawczych, m.in. nad modelowaniem rozproszenia [29, 30].

Zrekonstruowany obraz lokalizacyjny jest porównywany do obrazu referencyjnego z systemu planowania leczenia za pomocą różnych metod. Rejestracja obrazu może odbywać się w trybie automatycznym (porównanie do struktur kostnych, tkanek miękkich) bądź ręcznym (ryc. 4). Ważne jest, aby kierując się sytuacją kliniczną, wyznaczyć obszar, w którym — z punktu widzenia realizacji planu leczenia — dopasowanie struktur było najdokładniejsze [31-33]. Najnowsza wersja oprogramowania XVIElekta, pozwala na wyznaczenie kilku obszarów zainteresowania, tzw. multiclipbox. Dzięki temu możliwa jest jednoczesna analiza przesunięć i rotacji kilku struktur anatomicznych leżących blisko siebie, np. kręgów szyjnych i krtani [34, 35]. Jest to szczególnie istotne w przypadku radioterapii rejonu głowy i szyi, gdzie niewielkie odkształcenia w ułożeniu kręgosłupa szyjnego prowadzą do znacznych rotacji i przesunięć w obszarach napromienianych [36, 37]. Wyznaczając obszar dopasowania struktur w różnych okolicach anatomicznych, należy unikać, o ile klinicznie jest to uzasadnione, obejmowania struktur o dużej ruchomości, takich jakłopatki, główki kości udowych czy teżżuchwa, gdyż rozbieżność w ich położeniu może nie odzwierciedlać faktycznej różnicy w położeniu napromienianej objętości i narządów zdrowych [38].

Porównanie obrazu zebranego tuż przed seansem radioterapii z obrazem do planowania leczenia wnosi szereg istotnych klinicznie informacji. Uzyskane kierunki przesunięć i rotacji, które mogą być przełożone na ruch stołu w płaszczyźnie strzałkowej, czołowej i poprzecznej, umożliwią ułożenie pacjenta w pozycji maksymalnie zbliżonej do tej, w jakiej wykonano tomografię referencyjną, na bazie której opracowano plan leczenia. W ten sposób skutecznie ograniczane jest ryzyko popełnienia błędu geograficznego, a dawka deponowana jest w obszarach tarczowych zgodnie z założeniami planu leczenia [39]. Analiza serii obrazów wykonanych za pomocą kV CBCT w istotny sposób zmienia świadomość lekarza co do położenia obszarów tarczowych i narządów krytycznych względem siebie, a także rucho- 


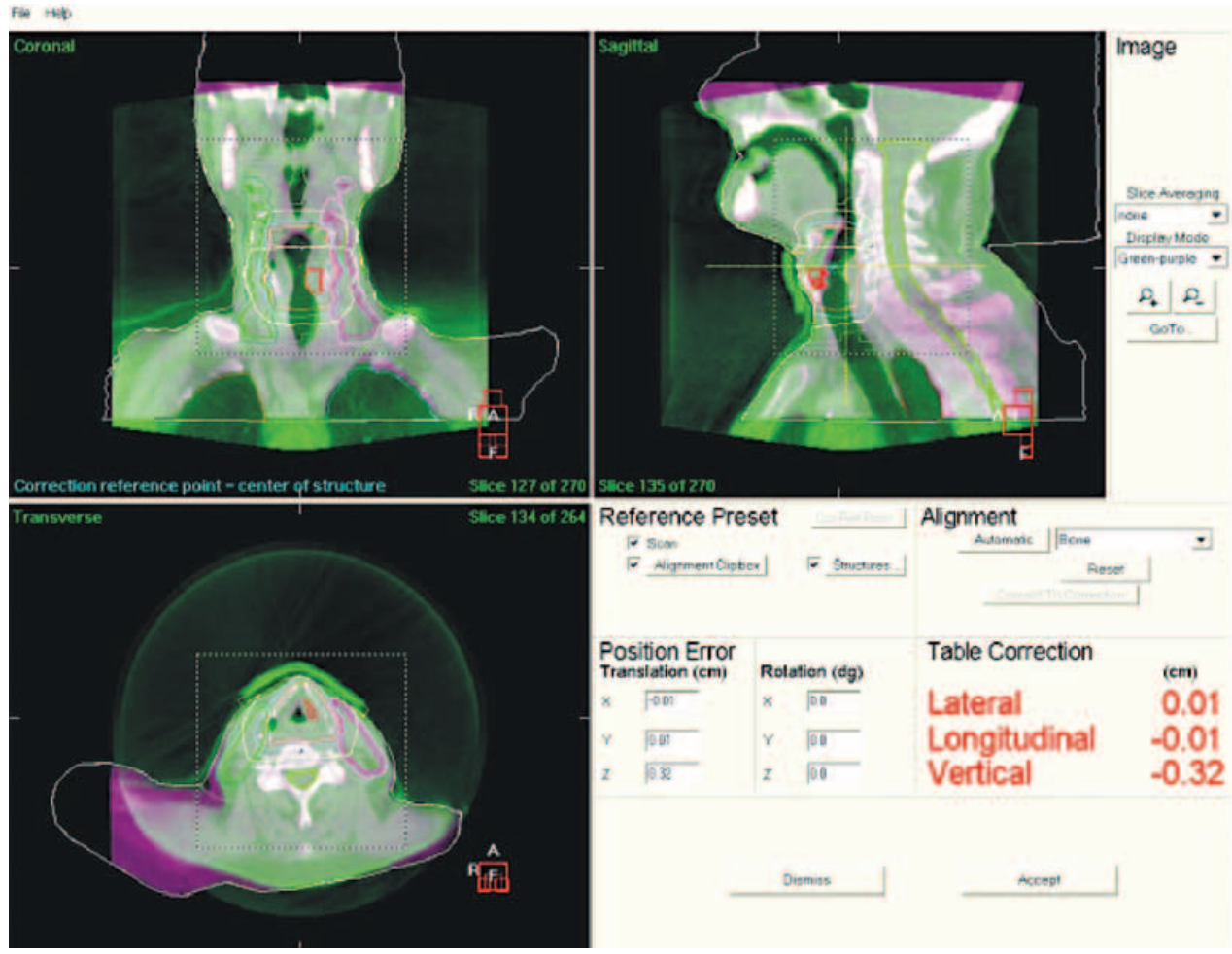

Rycina 3. Rejestracja obrazu referencyjnego z obrazem lokalizacyjnym, automatyczne dopasowane do struktur kostnych

mości tkanek miękkich względem struktur kostnych [40]. Zmienność położenia narządów wewnętrznych, szczególnie w zakresie jamy brzusznej i miednicy, zależna jest od szeregu czynników, takich jak wypełnienie pęcherza moczowego czy odbytnicy oraz stosowanej diety [41, 42]. Pomimo stosowania szczegółowych protokołów dotyczących przygotowania do radioterapii należy liczyć się z przemieszczaniem narządów względem siebie, co powinno być włączone na etapie planowania leczenia w obszar PTV [43]. Jednak weryfikacja ułożenia pacjenta za pomocą kV CBCT umożliwia zmniejszenie marginesu zapewniającego prawidłowy rozkład dawki w obszarze tarczowym, a tym samym zapewnia większą ochronę tkanek zdrowych [44, 45]. Podejmując decyzję o częstotliwości wykonywania kV CBCT, należy mieć na uwadze, iż jest to ekspozycja na promieniowanie jonizujące. Dodatkowa dawka, jaka jest deponowana przy codziennym IGRT, może być rzędu 1-2 Gy, co może mieć szczególne znacznie przy realizacji planu leczenia z wysokimi dawkami w narządach krytycznych [46]. Problem częstości wykonywania kV CBCT oraz dodatkowej dawki promieniowania nabiera szczególnego znaczenia u młodocianych pacjentów, którzy wykazują dużą podatność na niekorzystne działanie premiowania jonizującego $[47,48]$.

\section{IGRT — praktyka dziś i nadzieje na jutro}

Analiza obrazów lokalizacyjnych w trakcie leczenia umożliwia obserwację anatomicznych i morfologicznych zmian w zakresie guza nowotworowego, tj. zwiększenie lub zmniejszenie jego objętości, a co za tym idzie - może być wskazówką co do konieczności wykonania nowego planu leczenia $[49,50]$. IGRT w postaci trójwymiarowego obrazowania przed seansem napromieniania jest jednym z elementów nowej koncepcji realizacji radioterapii — radioterapii adaptacyjnej (Adaptive Radiation Therapy) [51, 52]. Jest to szczególnie istotne przy realizacji zaawansowanych technik radioterapii, takich jak IMRT, VMAT lub radioterapia stereotaktyczna, gdzie gradient dawki znacząco zmienia się w okolicy narządów krytycznych [1, 53, 54].

Wydaje się, iż pomimo licznych kontrowersji i trudności, jakie niesie weryfikacja ułożenia pacjenta na stole terapeutycznym tuż przed realizacją leczenia, technika IGRT w postaci kV CBCT stała się nieodzownym elementem współczesnej radioterapii. Szereg informacji uzyskanych w procesie weryfikacji pozycjonowania pacjenta, obok możliwości eliminacji błędu w położeniu obszarów tarczowych i narządów krytycznych, zmniejszenia marginesów wokół struktur tarczowych, obserwacji odpowiedzi na leczenie - umożliwia wysoką skuteczność leczenia energią jonizującą z zachowaniem dobrej jakości życia pacjenta $[55,56]$.

Kierunki prowadzonych badań wskazują, że już wkrótce dzięki rozwojowi technik komputerowych na stacjach XVI będzie możliwe dostosowanie planu leczenia do aktualnego ułożenia pacjenta. Być może analiza zmian $w$ tkankach zdrowych $w$ trakcie leczenia, np. obraz 


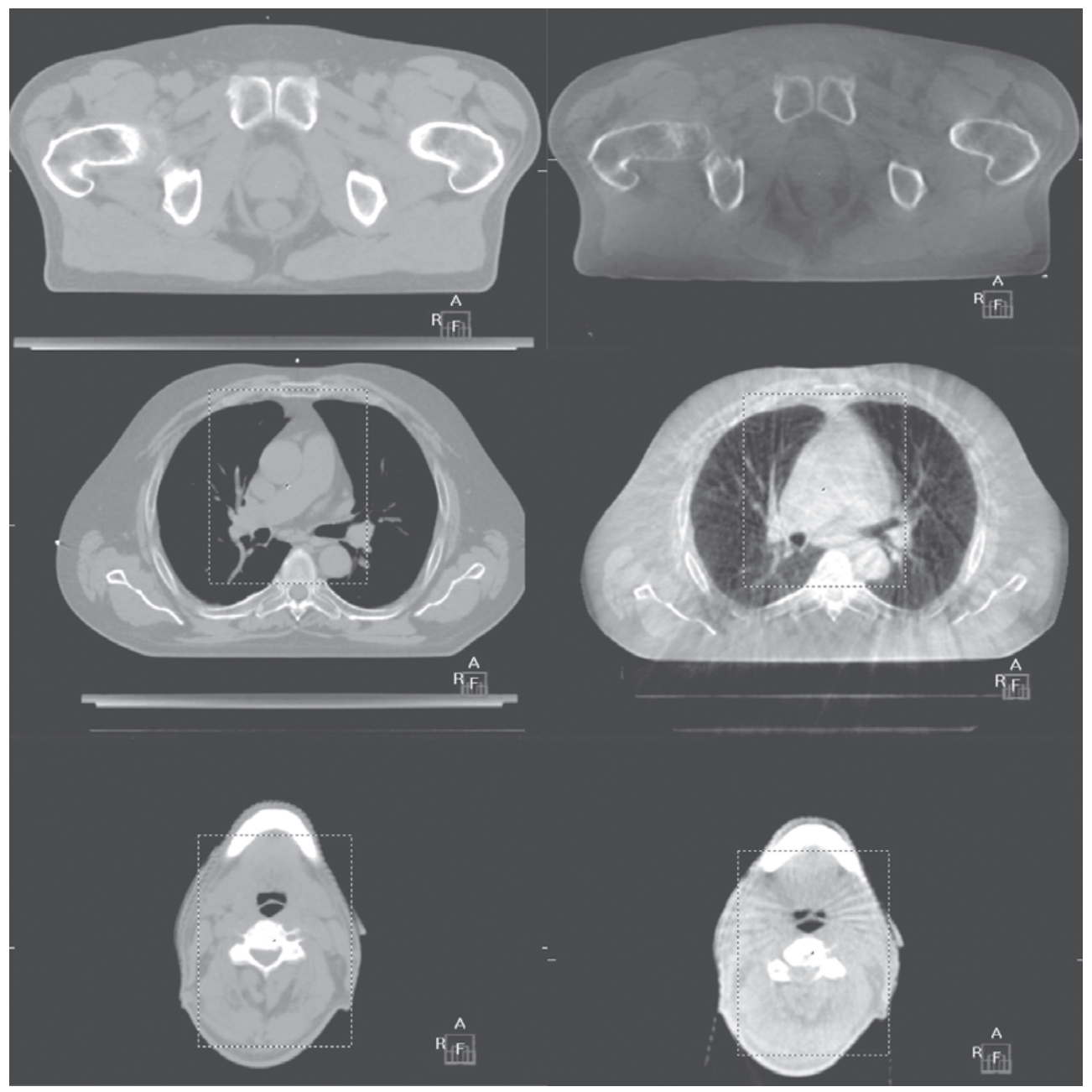

Rycina 4. Różnica w jakości obrazów poprzecznych uzyskanych za pomocą TK do planowania leczenia (lewa) oraz kV CBCT (prawa)

zmian popromiennych w płucach, będzie wykładnikiem prawdopodobieństwa wystąpienia późnego odczynu popromiennego, a obserwowane zmiany będą włączane w modyfikację planu leczenia wykonywanego przed każdą frakcją [57]. Można przypuszczać, że w następnym etapie funkcjonalne obrazowanie za pomocą IGRT (spektroskopia MR lub PET), umożliwiające obserwację zmian biologii guza wraz z następczą modyfikacją planu leczenia, stanie się kolejną furtką do otwarcia w radioterapii XXI wieku, zmierzającej do personalizacji leczenia.

\section{Dr n. med. Joanna Topczewska-Bruns}

Zakład Radioterapii

Białostockie Centrum Onkologii

ul. Ogrodowa 12, 15-027 Białystok

e-mail:asia@it-c.pl

Otrzymano: 26 listopada 2012 r.

Przyjęto do druku: 28 grudnia 2012 r.

\section{Piśmiennictwo}

1. Purdy JA. Dose to normal tissues outside the radiation therapy patient's treated volume: a review of different radiation therapy techniques. Health Phys 2008; 95: 666-776.

2. van Herk M, Bel A, Gilhuijs KG i wsp. Electronic portal imaging. Bull Cancer 1995; 82 Suppl 5: 601-606.

3. Bodusz D, Miszczyk L. Porównanie weryfikacji portalowej i ultrasonograficznej z zastosowaniem systemu Portal Vision i SonArray u. chorych na raka stercza poddanych radioterapii. Wsp Oncol 2010;14: 297-301.

4. De Neve W, Van den Heuvel F, De Beukeleer M i wsp. Routine clinical on-line portal imaging followed by immediate field adjustment using a tele-controlled patient couch. Radiother Oncol 1992; 24: 45-54.

5. el-Gayed AA, Bel A, Vijlbrief R i wsp. Time trend of patient setup deviations during pelvic irradiation using electronic portal imaging. Radiother Oncol 1993; 26: 162-171.

6. Van de Steene J, Van den Heuvel F, Bel A i wsp. Electronic portal imaging with on-line correction of setup error in thoracic irradiation: clinical evaluation. Int J Radiat Oncol Biol Phys 1998; 40: 967-976.

7. Murthy KK, Al-Rahbi Z, Sivakumar SS i wsp. Verification of setup errors in external beam radiation therapy using electronic portal imaging J Med Phys 2008; 33: 49-53.

8. Miszczyk L, Leszczyński W, Szczepanik K i wsp. Porównananie dwóch metod radioterapii sterowanej obrazem (IGRT) chorych na raka stercza -CBCT i 2D-2DKV. Przegl Lek 2008; 65: 315-320.

9. Majewski W, Prokop E, Tabor K, Kulik R. Ocena wczesnej tolerancji radioterapii kierowanej obrazowaniem (IGRT) u chorych na raka gruczołu krokowego. Onkologia Info 2011; 8: 37-44. 
10. Owen $\mathrm{R}$, Kron $\mathrm{T}$, Foroudi $\mathrm{F}$ i wsp. Comparison of $\mathrm{CT}$ on rails with electronic portal imaging for positioning of prostate cancer patients with implanted fiducial markers. Int J Radiat Oncol Biol Phys 2009; 74: 906-912.

11. Pouliot J, Bani-Hashemi A, Chen J i wsp. Low-dose megavoltage cone-beam CT for radiation therapy. Int J Radiat Oncol Biol Phys 2005; 61: 552-560.

12. Court L, Rosen I, Mohan R i wsp. Evaluation of mechanical precision and alignment uncertainties for an integrated CT/LINAC system. Med Phys 2003; 30: 1198-1210.

13. Jaffray DA, Siewerdsen JH, Wong JW i wsp. Flat-panel cone-beam computed tomography for image-guided radiation therapy. Int J Radiat Oncol Biol Phys 2002; 53: 1337-1349.

14. Ahn $\mathrm{PH}, \mathrm{Ahn} \mathrm{Al}$, Lee $\mathrm{CJ}$ i wsp. Random positional variation among the skull, mandible, and cervical spine with treatment progression during head-and-neck radiotherapy. Int J Radiat Oncol Biol Phys 2009; 73: 626-633.

15. Deng J, Chen Z, Roberts KB i wsp. Kilovoltage imaging doses in the radiotherapy of pediatric cancer patients. Int J Radiat Oncol Biol Phys 2012; 82: 1680-1688

16. Amer A, Marchant T, Sykes J I wsp. Imaging doses from the Elekta Synergy X-ray cone beam CT system. Br J Radiol 2007; 80: 476-482.

17. Walter $\mathrm{C}$, Boda-Heggemann J, Wertz $\mathrm{H}$ i wsp. Phantom and in-vivo measurements of dose exposure by image-guided radiotherapy (IGRT): MV portal images vs. kV portal images vs. cone-beam CT. Radiother Oncol 2007; 85: 418-423.

18. Osei EK, Schaly B, Fleck A i wsp. Dose assessment from an online kilovoltage imaging system in radiation therapy. J Radiol Prot 2009; 29: 37-50.

19. Zhang $\mathrm{Y}$, Yan $\mathrm{Y}$, Nath R i wsp. Personalized assessment of kV cone beam computed tomography doses in image-guided radiotherapy of pediatric cancer patients. Int J Radiat Oncol Biol Phys 2012; 83: 1649-1654.

20. Lu B, Lu H, Palta J. A comprehensive study on decreasing the kilovoltage cone-beam CT dose by reducing the projection number. J Appl Clin Med Phys 2010; 11: 3274.

21. Hyer DE, Hintenlang DE. Estimation of organ doses from kilovoltage cone-beam CT imaging used during radiotherapy patient position verification. Med Phys 2010; 37: 4620-4626.

22. Feldkamp LA, Davis LC, Kress JW: Practical cone-beam algorithm. J Opt Soc Am A 1984; 612-619.

23. Oh S, Kim S, Suh TS. How image quality affects determination of target displacement when using kilovoltage cone-beam computed tomography. J App/ Clin Med Phys 2006; 8: 101-107.

24. Thilmann C, Nill S, Tücking T i wsp. Correction of patient positioning errors based on in-line cone beam CTs: clinical implementation and first experiences. Radiat Oncol 2006; 1: 16.

25. Reitz I, Hesse BM, Nill S i wsp. Enhancement of image quality with a fast iterative scatter and beam hardening correction method for kV CBCT. Z Med Phys 2009; 19: 158-172.

26. Ning $R$, Tang $X$, Conover $D$. X-ray scatter correction algorithm for cone beam CT imaging. Med Phys 2004; 31: 1195-1202.

27. Graham SA, Moseley DJ, Siewerdsen JH i wps. Compensators for dose and scatter management in cone-beam computed tomography. Med Phys 2007; 34: 2691-2703.

28. Siewerdsen JH, Moseley DJ, Bakhtiar B i wsp. The influence of antiscatter grids on soft-tissue detectability in cone-beam computed tomography with flat-panel detectors. Med Phys 2004 ; 31: 3506-3520.

29. Spezi E, Downes P, Jarvis R i wsp. Patient-specific three-dimensional concomitant dose from cone beam computed tomography exposure in image-guided radiotherapy. Int J Radiat Oncol Biol Phys 2012; 83: 419-426.

30. Jarry G, Graham SA, Moseley DJ i wsp. Characterization of scattered radiation in kV CBCT images using Monte Carlo simulations. Med Phys 2006; 33: 4320-4329.

31. Ahn PH, Ahn Al, Lee CJ i wsp. Random positional variation among the skull, mandible, and cervical spine with treatment progression during head-and-neck radiotherapy. Int J Radiat Oncol Biol Phys 2009; 73: 626-633.

32. Smitsmans MH, Wolthaus JW, Artignan X i wsp. Automatic localization of the prostate for on-line or off-line image-guided radiotherapy. Int J Radiat Oncol Biol Phys 2004; 60: 623-635.

33. Moran MS, Lund MW, Ahmad M i wsp. Clinical implementation of prostate image guided radiation therapy: a prospective study to define the optimal field of interest and image registration technique using automated $\mathrm{x}$-ray volumetric imaging software. Technol Cancer Res Treat 2008; 7: 217-226.
34. van Beek S, van Kranen S, Mencarelli A i wsp. First clinical experience with a multiple region of interest registration and correction method in radiotherapy of head-and-neck cancer patients. Radiother Oncol 2010; 94: 213-217.

35. van Kranen S, van Beek S, Mencarelli A i wsp. Correction strategies to manage deformations in head-and-neck radiotherapy. Radiother Oncol 2010; 94: 199-205.

36. van Kranen S, van Beek S, Rasch C i wsp. Setup uncertainties of anatomical sub-regions in head-and-neck cancer patients after offline $C B C T$ guidance. Int J Radiat Oncol Biol Phys 2009; 73: 1566-1573.

37. Den RB, Doemer A, Kubicek G i wsp. Daily image guidance with cone-beam computed tomography for head-and-neck cancer intensity-modulated radiotherapy: a prospective study. Int J Radiat Oncol Biol Phys 2010; 76: 1353-1359.

38. Hasan Y, Kim L, Martinez A i wsp. Image guidance in external beam accelerated partial breast irradiation: comparison of surrogates for the lumpectomy cavity. Int J Radiat Oncol Biol Phys 2008; 70: 619-625.

39. Topolnjak R, Sonke JJ, Nijkamp J iwsp. Breast patient setup error assessment: comparison of electronic portal image devices and cone-beam computed tomography matching results. Int J Radiat Oncol Biol Phys 2010; 78: 1235-1243.

40. Muren LP, Smaaland R, Dahl O. Organ motion, set-up variation and treatment margins in radical radiotherapy of urinary bladder cancer. Radiother Oncol 2003; 69: 291-304.

41. Nijkamp J, de Jong R, Sonke JJ I wsp. Target volume shape variation during hypo-fractionated preoperative irradiation of rectal cancer patients. Radiother Oncol 2009; 92: 202-209.

42. Nijkamp J, Pos FJ, Nuver TT I wsp. Adaptive radiotherapy for prostate cancer using kilovoltage cone-beam computed tomography: first clinical results. Int J Radiat Oncol Biol Phys 2008; 70: 75-82.

43. ICRU Report62. Prescribing, recording and reporting photon beam therapy (supplement to ICRU Report 50) International Commission in Radiation Units and Measurements, Bethesda, 1999.

44. Rijkhorst EJ, Lakeman A, Nijkamp Ji wsp. Strategies for online organ motion correction for intensity-modulated radiotherapy of prostate cancer: prostate, rectum, and bladder dose effects. Int J Radiat Oncol Biol Phys 2009; 75: 1254-1260.

45. Rijkhorst EJ, van Herk M, Lebesque JV i wsp. Strategy for online correction of rotational organ motion for intensity-modulated radiotherapy of prostate cancer. Int J Radiat Oncol Biol Phys 2007; 69: 1608-1617.

46. Stock M, Palm A, Altendorfer A i wsp. IGRT induced dose burden for a variety of imaging protocols at two different anatomical sites. Radiother Oncol. 2012; 102: 355-363.

47. Nazmy MS, Khafaga Y, Mousa A i wsp. Cone beam CT for organs motion evaluation in pediatric abdominal neuroblastoma. Radiother Oncol 2012; 102: 388-392.

48. Kim S, Yoshizumi TT, Frush DP i wsp. Radiation dose from cone beam $C T$ in a pediatric phantom: risk estimation of cancer incidence. $A J R A m$ J Roentgenol 2010; 194: 186-190.

49. Barker JL Jr, Garden AS, Ang KK i wsp. Quantification of volumetric and geometric changes occurring during fractionated radiotherapy for head-and-neck cancer using an integrated CT/linear accelerator system. Int J Radiat Oncol Biol Phys 2004; 59: 960-970.

50. Wang W, Yang H, Hu W i wsp. Clinical study of the necessity of replanning before the 25 th fraction during the course of intensity-modulated radiotherapy for patients with nasopharyngeal carcinoma. Int $J$ Radiat Oncol Biol Phys 2010; 77: 617-621.

51. Hansen EK, Bucci MK, Quivey JM i wsp. Repeat CT imaging and replanning during the course of IMRT for head-and-neck cancer. Int J Radiat Oncol Biol Phys. 2006; 64: 355-362.

52. Ghilezan M, Yan D, Martinez A. Adaptive radiation therapy for prostate cancer.Semin Radiat Oncol. 2010; 20: 130-137.

53. Yamada Y, Lovelock DM, Bilsky MH. A review of image-guided intensity-modulated radiotherapy for spinal tumors. Neurosurgery 2007; 61 226-235; discussion 235.

54. Tejpal G, Jaiprakash A, Susovan B i wsp. IMRT and IGRT in head and neck cancer: Have we delivered what we promised? Indian J Surg Oncol 2010; 1: 166-185.

55. Azelie C, Gauthier M, Mirjolet C i wsp. Exclusive image guided IMRT vs. radical prostatectomy followed by postoperative IMRT for localized prostate cancer: a matched-pair analysis based on risk-groups. Radiat Oncol 2012; 7: 158.

56. Gill S, Thomas J, Fox C, Kron T i wsp. Acute toxicity in prostate cancer patients treated with and without image-guided radiotherapy. Radiat Oncol 2011; 6: 145

57. Bertelsen A, Schytte T, Bentzen SM i wsp. Radiation dose response of normal lung assessed by Cone Beam CT — a potential tool for biologically adaptive radiation therapy. Radiother Oncol 2011; 100: 351-355. 